\title{
Effect of dietary copper deficiency on iron metabolism in the pregnant rat
}

\author{
Henriette S. Andersen ${ }^{1}$, Lorraine Gambling ${ }^{1}$, Grietje Holtrop ${ }^{2}$ and Harry J. McArdle ${ }^{1 *}$ \\ ${ }^{1}$ Rowett Research Institute, Greenburn Road, Bucksburn, Aberdeen AB21 9SB, UK \\ ${ }^{2}$ BioSS, Rowett Research Institute, Greenburn Road, Bucksburn, Aberdeen AB21 9SB, UK \\ (Received 13 June 2006 - Revised 4 September 2006 - Accepted 6 September 2006)
}

\begin{abstract}
$\mathrm{Cu}$ and Fe metabolism are known to be linked, but the interactions during pregnancy are less well studied. In the present study we used rats to examine the effect of $\mathrm{Cu}$ deficiency during pregnancy on $\mathrm{Fe}$ and $\mathrm{Cu}$ levels in maternal and fetal tissue and on the gene expression profile of proteins involved in $\mathrm{Cu}$ and $\mathrm{Fe}$ metabolism in the placenta. Rats were fed diets with different $\mathrm{Cu}$ contents before and during pregnancy. Samples were collected on day 21 of gestation. $\mathrm{Cu}$ levels, ceruloplasmin activity and serum $\mathrm{Fe}$ all decreased in maternal serum of $\mathrm{Cu}$-deficient animals. Maternal liver Fe inversely correlated with liver $\mathrm{Cu}$. Placental $\mathrm{Cu}$ levels decreased with no change in $\mathrm{Fe}$. Fe and $\mathrm{Cu}$ levels both decreased in the fetal liver. The drop in maternal liver $\mathrm{Cu}$ was significantly correlated with a decrease in organ weight of fetal liver, lung and kidney. No changes were observed in mRNA expression of $\mathrm{Cu}$ transporter 1, Menkes P-type $\mathrm{Cu}$-ATPase 7A, Wilson P-type Cu-ATPase 7B, cytochrome-c oxidase, and $\mathrm{Cu}$ chaperone Atox 1 in the placenta of $\mathrm{Cu}$-deficient dams. Transferrin receptor 1 and the Fe-responsive element (IRE)-regulated divalent metal transporter 1 (DMT1) were up regulated; while ferroportin and non-IRE1-regulated DMT1 levels did not change. These data show that Cu deficiency during pregnancy not only has a direct effect on Fe levels but also regulates the expression of Fe transporters. The pattern closely mirrors that seen in Fe deficiency, suggesting that the changes are a consequence of the decrease in serum Fe, implying that the developing fetus not only suffers from $\mathrm{Cu}$, but also from Fe deficiency.
\end{abstract}

Placenta: Copper deficiency: Iron metabolism: Fetal programming

The metabolism of $\mathrm{Fe}$ and $\mathrm{Cu}$ are closely linked. Initial observations were made in 1927 , where Fe salts failed to cure anaemia in rats, while administration of $\mathrm{Cu}$ in the form of ashed foodstuff restored their $\mathrm{Hb}$ levels (Waddell et al., 1927). Since then, several studies have confirmed the relationship. In general, severe $\mathrm{Cu}$ deficiency causes changes in $\mathrm{Fe}$ metabolism leading to anaemia and liver Fe accumulation. The mechanism involved is not fully understood, but is probably related to decreased expression and levels of enzymes such as ceruloplasmin $(\mathrm{Cp})$ and hephaestin, which are multicopper oxidases required for $\mathrm{Fe}$ efflux. In support of this, mice with a mutation in hephaestin are anaemic and accumulate Fe in the gut (Vulpe et al., 1999) and patients with aceruloplasminaemia suffer from anaemia rather than $\mathrm{Cu}$ deficiency (Harris et al., 1995, 1998). Danzeisen et al. (2002) discovered a similar oxidase in a placenta cell line (BeWo cells) which is regulated by both $\mathrm{Cu}$ and $\mathrm{Fe}$ status.

We know that the dietary intake of $\mathrm{Cu}$ in women aged $19-24$ years is only $78 \%$ of the recommended daily intake (0.9-1.2 mg Cu/d; IOM, 2001). During pregnancy this may be even more of a problem as the need of micronutrients increases due to the requirements of a growing fetus. $\mathrm{Cu}$ is essential for fetal development and maternal dietary $\mathrm{Cu}$ deficiency can have both short- and long-term consequences (for a review, see Keen et al., 2003). The extent to which
$\mathrm{Cu}$ deficiency affects pregnancy outcome is very much dependent on the degree of $\mathrm{Cu}$ limitation. Severe $\mathrm{Cu}$ deficiency can lead to reproductive failure, early embryonic death and gross structural abnormalities in the fetuses (Prohaska \& Brokate, 2002). In contrast, moderate or mild $\mathrm{Cu}$ deficiency has little effect on either the number of live births and neonatal weight (Masters et al., 1983). However, the fetuses can suffer from lipid deposits in the connective tissue, cardiac haemorrhage, and skeletal defects (Wildman et al., 1995). It is therefore important to characterise the effect that $\mathrm{Cu}$ deficiency during pregnancy has on Fe metabolism and to elucidate the mechanism behind such alteration.

During pregnancy the transport of micronutrients from the mother to the fetus takes place across the placenta. The mechanism for $\mathrm{Cu}$ transport across the placenta to the fetus has not been clearly elucidated. It is assumed that $\mathrm{Cu}$ transporter 1 (Ctr1), a $\mathrm{Cu}$ transporter in the plasma membrane, is responsible for the translocation across the apical membrane (Zhou \& Gitschier, 1997). Virtually nothing is known about the transport mechanism for $\mathrm{Cu}$ once it is inside the placenta cells. Presumably it involves the same $\mathrm{Cu}$ chaperones as described for other tissues (for a recent review, see Prohaska \& Gybina, 2004). One of these $\mathrm{Cu}$ chaperones, Atox1, binds $\mathrm{Cu}$ and carries $\mathrm{Cu}$ to either Menkes P-type $\mathrm{Cu}$-ATPase 7A (ATP7A) or Wilson P-type Cu-ATPase 7B (ATP7B),

Abbreviations: ATP7A, Menkes P-type Cu-ATPase 7A; ATP7B, Wilson P-type Cu-ATPase 7B; Cp, ceruloplasmin; Ctr1, Cu transporter 1; DMT1, divalent metal transporter 1; IRE, Fe-responsive element.

* Corresponding author: Professor H. J. McArdle, fax +44 1224 716622, email H.McArdle@ rowett.ac.uk 
depending on the tissue. In the placenta, both ATP7A and ATP7B are expressed, and their specific locations may be relevant to the paths followed by $\mathrm{Cu}$ through the placenta (Hardman et al., 2004).

The uptake of Fe into the placenta is through transferrin receptor-mediated endocytosis. In species with a haemochorial placenta such as rodents and man, Fe attached to transferrin binds to transferrin receptor on the brush-border membrane of the placenta where it is internalised in endosomes (McArdle et al., 1985a,b). The endosomes are acidified and the $\mathrm{Fe}$ released. It moves into the cytoplasm, presumably via the divalent metal transporter 1 (DMT1), and is carried across the placenta and into fetal circulation. The efflux is probably through Fe-regulated gene 1 (ferroportin) and the $\mathrm{Fe}_{-}{ }^{2+}$ is oxidised to $\mathrm{Fe}^{-}{ }^{3+}$ before incorporation into fetal transferrin by a ferroxidase similar, but not identical, to Cp (Danzeisen et al., 2002). The different genes respond differently to $\mathrm{Fe}$ deficiency. There is an increase in expression of transferrin receptor 1 and the Fe-responsive element (IRE)-regulated form of DMT1. In contrast, the non-IRE-regulated form of DMT1 and ferroportin show no changes in expression levels (Gambling et al., 2001).

Present data on the effect of mild $\mathrm{Cu}$ deficiency on maternal to fetal transport of Fe are contradictory. A study by Wapnir et al. (1996) showed that fetal liver Fe levels increased when exposed to $\mathrm{Cu}$-deficient diets, whereas another study reported a decrease (Ebesh et al., 1999).

The purpose of the present study was to determine the effect of mild $\mathrm{Cu}$ deficiency on maternal and fetal $\mathrm{Cu}$ and $\mathrm{Fe}$ metabolism, growth and development. In order to understand the mechanism for any changes in fetal $\mathrm{Cu}$ and $\mathrm{Fe}$ metabolism we examined whether there was an altered expression of genes encoding the proteins of $\mathrm{Cu}$ and $\mathrm{Fe}$ transport in the placenta.

\section{Methods}

\section{Experimental diets}

The diets were based on dried egg albumin and conformed to American Institute of Nutrition guidelines for laboratory animals (American Institute of Nutrition, 1980). $\mathrm{CuSO}_{4}$ was added to achieve levels of added $\mathrm{Cu}$ of 5 (control diet), or $2.5(50 \%$ control $\mathrm{Cu})$ and $0.75 \mathrm{mg} \mathrm{Cu} / \mathrm{kg}(15 \%$ control $\mathrm{Cu})$ of diet. The diets were identical in all other respects. Fe concentration was held at $50 \mu \mathrm{g} \mathrm{Fe} / \mathrm{kg}$. Dietary ingredients were purchased from Mayjex Ltd (Chalfont St Peter, Bucks, UK), BDH Chemicals (Poole, Dorset, UK) or Sigma (Poole, Dorset, UK).

\section{Experimental animals}

All experimental procedures were approved by the Home Office and the Ethics Committee at the Rowett Research Institute and conducted in accordance with the UK animals (Scientific Procedures) Act, 1986. Experiments were performed using weanling female rats of the Rowett Hooded Lister strain, bred at the Rowett Research Institute. They were grouped housed in cages, under a $12 \mathrm{~h}$ light-dark cycle and with constant temperature and humidity. All animals were fed ad libitum and provided with distilled water.
Twenty-four female weanling rats were fed the control diet for 4 weeks, before being randomly assigned to one of the three diet treatments (eight rats per treatment), control or $\mathrm{Cu}$-deficient diet having 50 and $15 \% \mathrm{Cu}$ levels compared with the control for 4 weeks before mating.

\section{Tissue samples}

On day 21 of gestation, the dams were killed by stunning and cervical dislocation. The numbers of fetuses and placentas were counted, and the number of resorption sites observed in the uterus was recorded. Placentas associated with healthy fetuses were weighed and frozen in liquid $\mathrm{N}_{2}$ before being stored at $-80^{\circ} \mathrm{C}$. Fetal livers, hearts, kidneys, and lungs were collected from six fetuses, chosen from each mother at random, rapidly dissected, weighed and frozen in liquid $\mathrm{N}_{2}$. Livers, kidneys, spleen, hearts, lungs, pancreas, ovary and adrenals were dissected from all dams, weighed and frozen in liquid $\mathrm{N}_{2}$ before being stored at $-80^{\circ} \mathrm{C}$. Maternal blood was collected in non-heparinised tubes and centrifuged at $1000 \mathrm{~g}$, at $4^{\circ} \mathrm{C}$, for $10 \mathrm{~min}$. The resulting serum was stored in metal-free Eppendorf tubes (Axygen Scientific, Union City, CA, USA) at $-80^{\circ} \mathrm{C}$.

\section{Atomic absorption spectrophotometric analysis}

$\mathrm{Fe}$ and $\mathrm{Cu}$ levels in maternal serum and in tissue from dams and fetuses were measured by graphite furnace atomic absorption spectroscopy (AAnalyser6600; Perkin Elmer, Norwalk, CT, USA) according to standard procedures, as previously described (Gambling et al., 2001). To differentiate between haeme and non-haeme $\mathrm{Fe}$ in the serum and tissue, samples were treated with $20 \%(\mathrm{w} / \mathrm{v})$ TCA, heated to $96^{\circ} \mathrm{C}$ for $5 \mathrm{~min}$ and the supernatant fraction collected as described previously (Gambling et al., 2002). Quality controls were included as necessary. Repeat measurements gave variance less than $15 \%$. Standards were obtained from BDH Laboratory Supplies (Poole, Dorset, UK). The laboratories are certified to ISO 9001.

\section{Real-time quantitative reverse transcription polymerase chain reaction}

Complementary DNA PCR primers for the rat were designed using Primer Express (version 1.5; Applied Biosystems, Foster City, CA, USA) software from DNA sequences obtained from GenBank (Table 1). All primer sets had a calculated annealing temperature of $58^{\circ} \mathrm{C}$. Primers were synthesised by MWG Biotech (Ebersberg, Germany).

Total RNA was isolated from tissue following the method of Chomczynski \& Sacchi (1987) and treated with DNAse I (Boehringer Mannheim, Mannheim, Germany). First strand complementary DNA was synthesised by priming with hexamers using the Taqman RT Reagent Kit (Applied Biosystems). Reverse transcription was performed in $20 \mu \mathrm{l}$ reactions using $200 \mathrm{ng}$ of DNAse-treated RNA.

Real-time PCR amplification and analysis was performed using a 7700 Sequence Detection System (Applied Biosystems) and ABI prism software (version 1.9; Applied Biosystems). Reactions were performed in $25 \mu \mathrm{l}$ volume with $300 \mathrm{nM}$ primers and $5 \mu \mathrm{l}$ cDNA. $\mathrm{MgCl}_{2}$, nucleotides, buffer 
Copper and iron metabolism in pregnancy

Table 1. Description of the primers used for real-time reverse transcription polymerase chain reaction analysis

\begin{tabular}{lccccr}
\hline Gene name & Species & GenBank accession no. & Forward primer & Reverse primer $^{*}$ & Fragment (bp) \\
\hline Transferrin receptor 1 & Rat & M58040 & $1757-1779$ & $1818-1838$ & 82 \\
DMT1 & Rat & AF008439 & $2168-2188$ & $2228-2247$ & 80 \\
DMT1 (non-IRE) & Rat & AF029757 & $1650-1673$ & $1700-1722$ & 73 \\
Ferroportin & Rat & AF394785 & $1549-1573$ & $1606-1626$ & 78 \\
Ctr1 & Rat & AF268030 & $17-34$ & $76-96$ & 80 \\
ATP7A & Rat & NM052803 & $1996-2021$ & $2055-2082$ & 87 \\
ATP7B & Rat & NM012511 & $1766-1786$ & $1815-1837$ & 72 \\
Cu chaperone Atox1 & Rat & NM_053359 & $99-116$ & $180-200$ & 102 \\
18S2 & Rat & V01270 & $941-959$ & $986-1006$ & 66 \\
\hline
\end{tabular}

DMT1, divalent metal transporter 1; IRE, Fe-responsive element; ATP7A, Menkes P-type Cu-ATPase 7A; ATP7B, Wilson P-type Cu-ATPase 7B.

* Coordinates according to the GenBank DNA sequence.

and Taq DNA polymerase were included in the SYBR Green Master Mix (Applied Biosystems). Amplification specificity was assessed by agarose gel electrophoreses.

Standard curves were generated from increasing amount of cDNA made from total rat placenta control RNA. The $\mathrm{C}_{\mathrm{T}}$ values were used to calculate and plot a linear regression line by plotting the logarithm of template concentration ( $x$-axis) against the $\mathrm{C}_{\mathrm{T}}$ value ( $y$-axis). These regression lines were used to calculate the expression level (ng total RNA) for unknown samples. Data were normalised to the expression levels of $18 \mathrm{~S}$. For comparison between groups, controls were taken as $100 \%$.

\section{Ceruloplasmin assay}

Maternal serum and placenta tissue from the control and $15 \%$ $\mathrm{Cu}-$ groups were analysed for $\mathrm{Cp}$ oxidase activity. The placentas were homogenised in $0.02 \mathrm{M}-\mathrm{N}^{\prime}$-(2-hydroxyethyl)piperazine-N-2-ethanesulfonic acid, $0.25 \mathrm{M}$-sucrose buffer with a homogeniser (Ultra Turrax T25; IKA Labortechnik, Stauful, Germany). The homogenates were fractionated into a membrane and soluble fraction by centrifugation at $50000 \mathrm{rpm}$ $(108000 \mathrm{~g})$ at $4^{\circ} \mathrm{C}$ for $1 \mathrm{~h}$. Cp oxidase activity (ferroxidase activity) was determined by measuring its $p$-phenylenediamine oxidase activity in the presence and absence of $150 \mathrm{~mm}$ sodium azide (Sunderman et al., 1984; Gambling et al., 2004). Briefly, the samples were incubated in $200 \mathrm{~mm}$-acetate buffer, $\mathrm{pH} 5 \cdot 5$, at $37^{\circ} \mathrm{C}$ for $1 \mathrm{~h}$ and read at $560 \mathrm{~nm}$ (ELx800 UV plate reader; Bio-Tek Instruments, Inc., Winooski, VT, USA). Human Cp (Vital Products, Boynton Beach, FL, USA) was used as a standard. Azide-sensitive ferroxidase activity was expressed as $\mu \mathrm{g} \mathrm{Cp} / \mathrm{mg}$ protein.

\section{Statistics}

For each dam, fetal data were averaged and the data recorded as a single point. All results are presented as mean values with their standard errors. A minimum of six measurements for each diet group was used for analysis. The effect of diet was assessed by one-way ANOVA and, as appropriate, either statistically or biologically, treatment means were also compared with a post hoc $t$ test. Linear regression was used to look for relationships between $\mathrm{Cu}$ and $\mathrm{Fe}$ levels. Relationships between organ weight and body weight were investigated using allometric analysis (linear regression of (natural) $\log$ (organ weight) on $\log$ (body weight)). This approach was extended to investigate relationships between fetal organ weight, litter size, and maternal liver $\mathrm{Cu}$ concentrations by means of multiple linear regressions using (natural) logtransformed data.

For real-time PCR the change in expression between mRNA levels of the control group and the 50 and $15 \%$ Cu-deficient groups were presented as the ratio of $18 \mathrm{~S}$ expressions in each particular sample. Each group contained amplified cDNA from five to eight animals, and the average of these measurements was used to calculate mean and SEM. Significant differences between treated and control groups were determined using one-way ANOVA. Statistical analyses were performed in GenStat (8th edition, release 8.1; VSN International Ltd, Hemel Hempstead, Herts, UK).

\section{Results}

There was no effect of dietary treatment on body-weight gain of the dams, number of fetuses, resorption sites or packed cell volume (Table 2). In addition, no significant changes were observed for any of the maternal organs examined (based on allometry analysis with regression of log (organ weight) on $\log$ (body weight) + diet; data not shown) .

A significant $(P<0.001)$, diet-induced, decrease in maternal serum $\mathrm{Cu}$ levels was observed (Fig. 1(A)), together with a parallel decrease in Fe levels (Fig. 1(B); $P=0.020 ; r^{2}$ 0.35).

Maternal liver $\mathrm{Cu}$ levels were significantly $\left(P<0.001 ; r^{2}\right.$ $0.59)$ decreased as levels in the diet were reduced (Fig. 2(A)). When comparing the dietary extremes of the control and the $15 \% \mathrm{Cu}$, the maternal liver Fe level significantly increased $(P=0.033$; two-tailed Mann-Whitney $t$ test $)$ (Fig. 2(B)).

Between the two extremes of dietary $\mathrm{Cu}, 5 \mathrm{mg} / \mathrm{kg}$ (control) and $0.75 \mathrm{mg} / \mathrm{kg}$ ( $15 \%$ of control) Cu oxidase activity was significantly reduced in maternal serum and in the soluble fraction of the placenta (presumably representing serum contamination of the soluble fraction) (Table 3). Cu oxidase activity in the membrane fraction of the placenta did not change.

In other tissues, we measured both total and non-haeme Fe. Overall, the changes in maternal $\mathrm{Cu}$ status were reflected by alterations in both placental and fetal parameters. When comparing the dietary extremes of the control and the $15 \% \mathrm{Cu}$, the placental $\mathrm{Cu}$ levels decreased ( $P=0 \cdot 043$; two-tailed MannWhitney $t$ test) (Fig. 2(C)) while there were no changes in either placental non-haeme (not shown) or total $\mathrm{Fe}$ (Fig. 2(D)). The fetal liver $\mathrm{Cu} \quad\left(P=0.003 ; r^{2} 0.40\right)$ 
Table 2. Effect of maternal copper deficiency in the rat on growth and fertility (Mean values with their standard errors; six to eight rats per group)

\begin{tabular}{|c|c|c|c|c|c|c|}
\hline \multirow[b]{3}{*}{ Diet group } & \multicolumn{6}{|c|}{ Cu level } \\
\hline & \multicolumn{2}{|c|}{$5 \mathrm{mg} / \mathrm{kg}$} & \multicolumn{2}{|c|}{$2.5 \mathrm{mg} / \mathrm{kg}$} & \multicolumn{2}{|c|}{$0.75 \mathrm{mg} / \mathrm{kg}$} \\
\hline & Mean & SEM & Mean & SEM & Mean & SEM \\
\hline Maternal body weight (g) & 320.73 & 3.95 & $319 \cdot 83$ & 9.05 & 334.82 & $5 \cdot 76$ \\
\hline Total no. of fetuses ( $\mathrm{n} /$ per dam) & 14.43 & 0.35 & 11.67 & 1.98 & 13.67 & 1.09 \\
\hline Resorption sites ( $n /$ dam) & 0.29 & $0 \cdot 17$ & $1 \cdot 17$ & 0.48 & 1.00 & 0.63 \\
\hline Packed cell volume (\%) & $40 \cdot 71$ & 0.91 & $40 \cdot 20$ & $1 \cdot 16$ & 38.83 & 0.70 \\
\hline
\end{tabular}

and non-haeme Fe levels $\left(P<0.001 ; r^{2} 0.47\right)$ were significantly correlated to maternal $\mathrm{Cu}$ status (Figs. 3(A) and (B)).

Data regarding the influence of maternal $\mathrm{Cu}$ deficiency on fetal development can be analysed in two ways: related to maternal dietary $\mathrm{Cu}$ intake or related to maternal liver $\mathrm{Cu}$ levels. We consider the latter approach more appropriate as it provides a better indicator for $\mathrm{Cu}$ status and have investigated the influence of maternal liver $\mathrm{Cu}$ concentration on fetal weight and organ weights, allowing for a correction for litter size (Fig. 4). There was a tendency to a reduced fetal weight with low maternal liver $\mathrm{Cu}$ levels $(P=0.053$; data not shown). Maternal liver $\mathrm{Cu}$ levels were positively correlated to the organ weight of fetal liver $\left(P=0.023 ; r^{2} 0 \cdot 26\right)$,
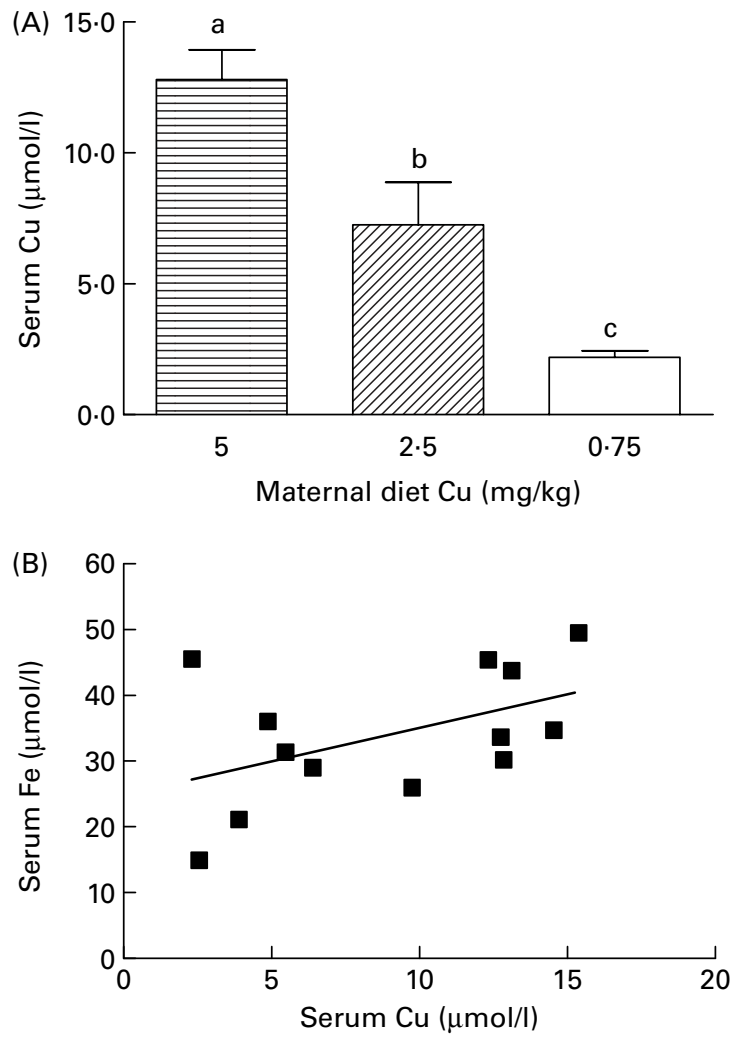

Fig. 1. (A) Maternal serum Cu concentration in pregnant female rats according to the $\mathrm{Cu}$ content of the maternal diet (eight rats per diet group). Values are means, with their standard errors represented by vertical bars. ${ }^{a, b, c}$ Mean values with unlike letters were significantly different $(P<0.001$; ANOVA). (B) Relationship between maternal serum $\mathrm{Cu}$ and $\mathrm{Fe}$ concentration in pregnant female rats $\left(r^{2} 0.35 ; P=0.020\right)$. lung $\left(P=0.022 ; r^{2} 0.26\right)$ and kidney $\left(P=0.040 ; r^{2} 0.21\right)$, which was lower for low maternal liver $\mathrm{Cu}$ concentration (Fig. 4). There was no alteration in relative heart size $(P>0 \cdot 1$; data not shown).

Examination of genes involved in $\mathrm{Cu}$ and $\mathrm{Fe}$ metabolism revealed a change in expression levels of specifically genes involved in Fe metabolism. In the placenta, mRNA levels of transferrin receptor 1 were significantly increased $(P=0.0014$; $r^{2}$ 0.48) with decreasing maternal liver Cu levels (Fig. 5(A)).

The expression of the two DMT1 transcripts, the Fe-responsive form (IRE)-regulated and non-IRE-regulated showed different patterns in the maternal placenta. The IRE-regulated transcript increased $\left(P=0 \cdot 013 ; r^{2} 0 \cdot 33\right)$ with decreasing levels of $\mathrm{Cu}$ (Fig. 5(B)), while the non-IRE-regulated form of DMT1 did not change $(P=0 \cdot 39)$ (Fig. 5(C)). Ferroportin levels did not change significantly and there were no significant changes in the mRNA level of any of the $\mathrm{Cu}$ proteins examined, ATP7A and B, Ctr1, or $\mathrm{Cu}, \mathrm{Zn}$ superoxide dismutase 1 (data not shown).

\section{Discussion}

The aim of the present study was to determine the effect of mild dietary $\mathrm{Cu}$ deficiency during pregnancy in rats on maternal growth, on pregnancy outcome and on $\mathrm{Cu}$ and $\mathrm{Fe}$ status of both the mothers and their fetuses. The data show that the severity of $\mathrm{Cu}$ deficiency had no effect on maternal growth and number of fetuses. The present results confirm previous data showing that $\mathrm{Cu}$ deficiency during pregnancy in the rat does not affect maternal outcome (Ebesh et al., 1999).

Interestingly, we found that maternal liver $\mathrm{Cu}$ status affected fetal organ weight, and also tended to affect fetal body weight, with fetal liver, lung and kidney being reduced in weight as maternal liver $\mathrm{Cu}$ levels decreased. Allometry analyses indicated strong significant $(P<0.001$; data not shown) linear relationships between the log-transformed organ weights and log-transformed fetal weight. In a previous study, no effect was seen in fetal organ weight (Ebesh et al., 1999). One likely cause of the difference between the present study and the one by Ebesh et al. (1999) is that the latter fed rats a Cu-deficient diet $(0.54-0.58 \mathrm{mg} \mathrm{Cu} / \mathrm{kg}$ diet $)$ only from gestational day 10 until delivery. Our protocol gave the dams a $\mathrm{Cu}$-deficient diet for 7 weeks by the end of gestation. Data from the present study and from a recent publication (Andersen et al. 2006) suggest that growth might be regulated earlier on in pregnancy where major organ development occurs - a period during development not covered in 
(A)

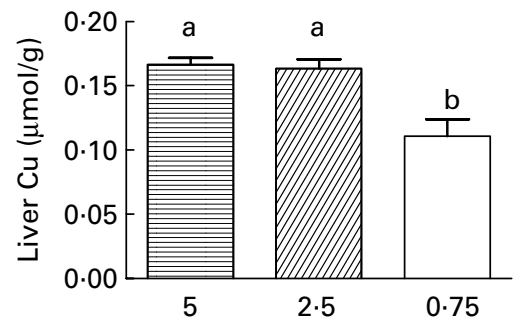

(B)

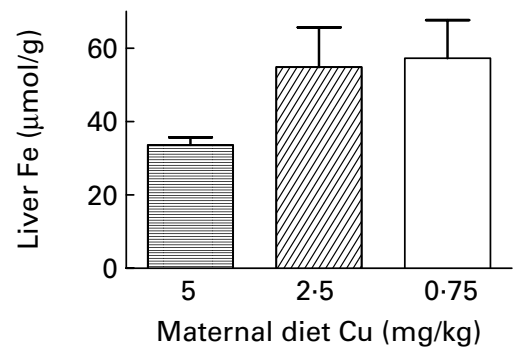

(C)

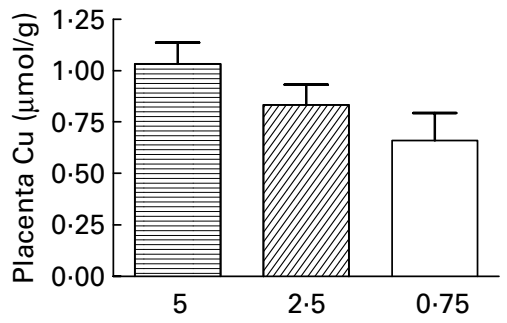

(D)

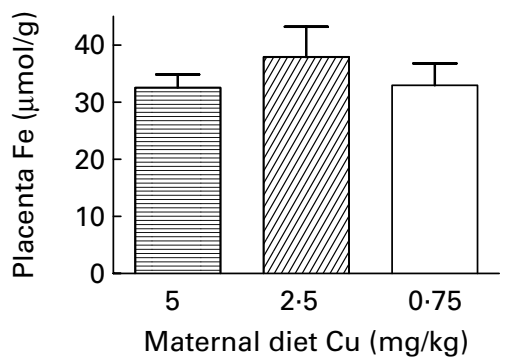

Fig. 2. Maternal liver $\mathrm{Cu}(\mathrm{A})$, liver Fe $(\mathrm{B})$, placenta $\mathrm{Cu}(\mathrm{C})$ and placenta Fe according to the Cu content of the maternal diet (eight rats per diet group). Values are means, with their standard errors represented by vertical bars. ${ }^{a, b}$ Mean values with unlike letters were significantly different $(P=0.033$; ANOVA).

the study by Ebesh et al. (1999). However, it should also be pointed out that the relationship between size and $\mathrm{Cu}$ content in the present study is dependent on correcting for litter size and, as will be apparent from Fig. 4, one particular data point at a maternal $\mathrm{Cu}$ content of about $2 \mu \mathrm{mol} / \mathrm{g}$. We have no reason to exclude this point, but it does mean the present results should be treated with some caution.

Our model of mild maternal $\mathrm{Cu}$ deficiency causes significant changes in hepatic $\mathrm{Cu}$ and $\mathrm{Fe}$ levels, but maternal packed cell volume remains unchanged, suggesting only a mild state of $\mathrm{Cu}$ deficiency. Although placenta $\mathrm{Fe}$ levels appeared not to be affected by the reduced dietary intake of $\mathrm{Cu}$, fetal liver Fe levels were reduced. Placental Fe would not be expected to change. It acts as a conduit for Fe. As such, the levels of Fe in the liver are a better indicator of transport activity than levels in the placenta itself. The effects of $\mathrm{Cu}$ on $\mathrm{Fe}$ metabolism were opposite in the mother and the fetus; maternal liver $\mathrm{Fe}$ increased, whereas fetal liver $\mathrm{Fe}$ content decreased. Our data show that the primary

Table 3. Ceruloplasmin (Cp) activity in placenta and serum of gestational day 21 copper-deficient rats

(Mean values with their standard errors of the mean; three to eight rats per group)

\begin{tabular}{|c|c|c|c|c|}
\hline \multirow{3}{*}{ Diet group } & \multicolumn{4}{|c|}{ Cu level } \\
\hline & \multicolumn{2}{|c|}{$5 \mathrm{mg} / \mathrm{kg}$} & \multicolumn{2}{|c|}{$0.75 \mathrm{mg} / \mathrm{kg}$} \\
\hline & Mean & SEM & Mean & SEM \\
\hline 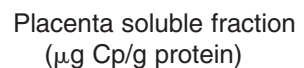 & $4 \cdot 29$ & 0.79 & $1.62^{*}$ & 0.23 \\
\hline $\begin{array}{l}\text { Placenta membrane } \\
\text { fraction ( } \mu \mathrm{g} \mathrm{Cp} / \mathrm{g} \\
\text { protein) }\end{array}$ & 11.02 & 0.73 & 11.07 & $1 \cdot 18$ \\
\hline $\begin{array}{l}\text { Maternal serum } \\
\quad(\mu \mathrm{g} \mathrm{Cp} / \mathrm{g} \text { protein) }\end{array}$ & $11186 \cdot 1$ & 1082 & $6639 \cdot 2^{*}$ & 516 \\
\hline
\end{tabular}

${ }^{*}$ Mean value was significantly different from that of the $5 \mathrm{mg} / \mathrm{kg}$ group $(P<0.05)$. consequence of low dietary $\mathrm{Cu}$ is a compromised maternal to fetal transport of $\mathrm{Cu}$ and $\mathrm{Fe}$. This finding is in agreement with previously published data by Ebesh et al. (1999).

The expression data in the placenta suggest that it is responding in the same way as it does to a directly induced Fe deficiency. We have previously shown that maternal Fe deficiency results in increased expression of transferrin receptor 1 and DMT1 and no change in ferroportin expression. In the present study we obtained the same results. The data also give some intriguing insights into the possible regulation of Fe transport. Hepcidin
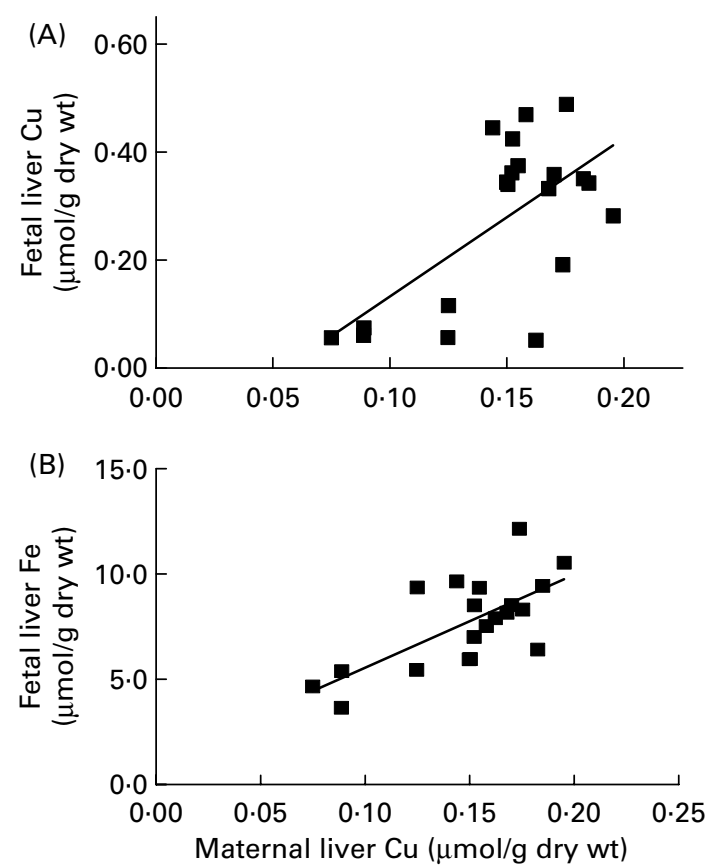

Fig. 3. (A) Relationship between maternal liver $\mathrm{Cu}$ and fetal liver $\mathrm{Cu}\left(r^{2} 0.40\right.$; $P=0.003$ ). (B) Relationship between maternal liver $\mathrm{Cu}$ and fetal liver nonhaeme $\mathrm{Fe}\left(r^{2} 0.47 ; P<0.001\right)$. 

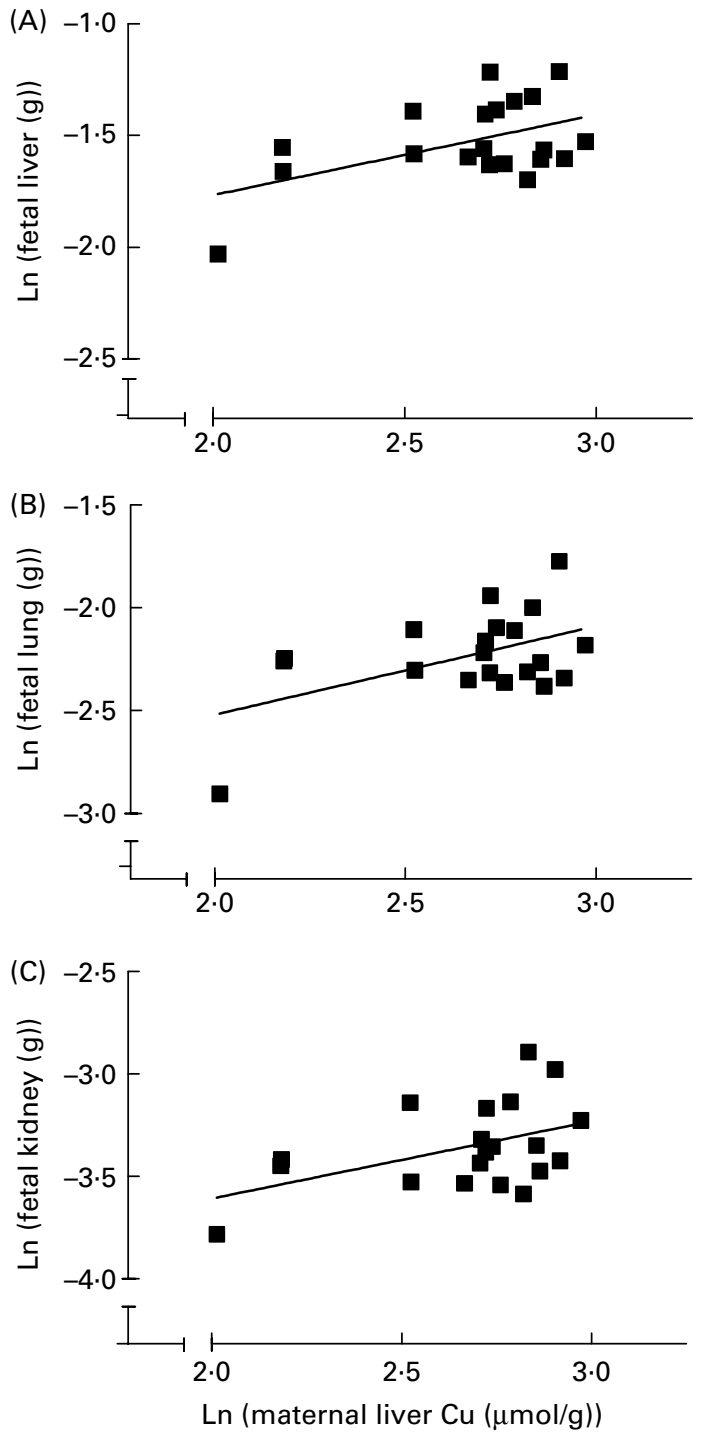

Fig. 4. (A) Relationship between maternal liver $\mathrm{Cu}$ and $\mathrm{Ln}$ fetal liver weight $\left(r^{2} 0.26 ; P=0.023\right)$. (B) Relationship between maternal liver $\mathrm{Cu}$ and $\mathrm{Ln}$ fetal lung weight $\left(r^{2} 0.26 ; P=0.022\right)$. (C) Relationship between maternal liver $\mathrm{Cu}$ and $\operatorname{Ln}$ fetal kidney weight $\left(r^{2} 0.21 ; P=0.040\right)$.

is a small peptide thought to be involved in the regulation of $\mathrm{Fe}$ absorption and in the regulation of systemic Fe metabolism. Its expression in the liver is proportional to $\mathrm{Fe}$ requirements (Mazur et al., 2003). Given the increase in maternal liver Fe, therefore, one would expect an increase in hepcidin expression. This would result in a decrease in expression of transporters in the gut and, if maternal hepcidin regulated placental transport, the placenta. This is clearly not the case, as the expression of the placenta transporters increases, so we can conclude that maternal hepcidin is not involved in regulation of transplacental Fe transfer.

In contrast to $\mathrm{Fe}$, regulation of $\mathrm{Cu}$ transport seems to occur primarily by altered location of the transport proteins. The mechanism for $\mathrm{Cu}$ transport across the placenta to the fetus has not been clearly elucidated. It is assumed that Ctr1, a $\mathrm{Cu}$ transporter in the plasma membrane, is responsible for the translocation across the apical membrane (Zhou \& Gitschier, 1997). Ctr1 is expressed in the mammalian placenta
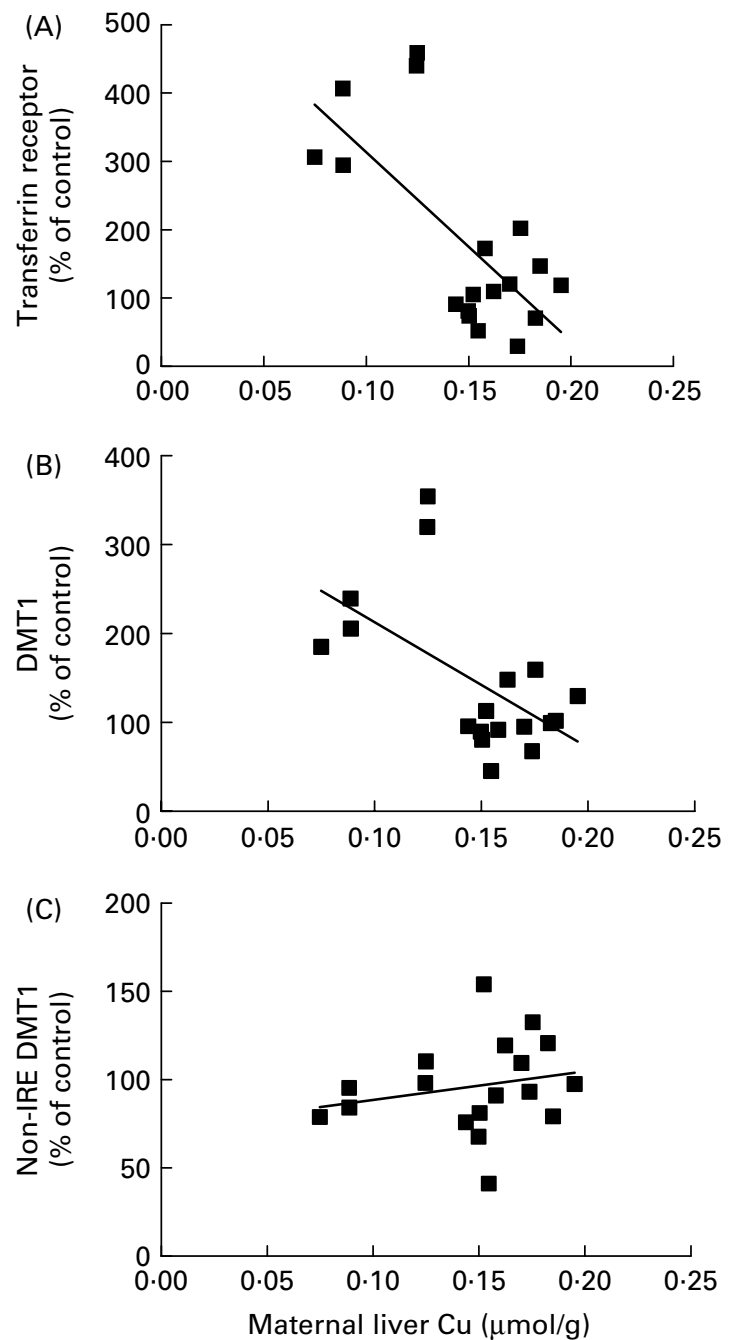

Fig. 5. (A) Relationship between maternal liver $\mathrm{Cu}$ and placenta transferrin receptor mRNA $\left(r^{2} 0.48 ; P=0.0014\right)$. (B) Relationship between maternal liver $\mathrm{Cu}$ and placenta divalent metal transporter 1 (DMT1) $\left(r^{2} \quad 0.33\right.$; $P=0.013$ ). (C) Relationship between maternal liver $\mathrm{Cu}$ and placenta non-Feresponsive element (IRE) DMT1 $(P=0.39)$.

(Gambling et al., 2004; Hardman et al., 2006). The regulation of $\mathrm{Ctr} 1$ is tissue specific and dependent on $\mathrm{Cu}$ status (Bauerly et al., 2005; Kuo et al., 2006). The data presented here showed no changes in expression of Ctr1 mRNA levels in the placenta. The absence of changes in $\mathrm{Ctr} 1 \mathrm{mRNA}$ levels by dietary $\mathrm{Cu}$ deficiency is not unexpected. Studies in postnatal $\mathrm{Cu}$-deficient rats showed no changes at the mRNA level in liver, intestine and hypothalamus (Lee et al., 2000; Kuo et al., 2006) and a recent study using a placenta cell line (Jeg-3 cells) showed no change in Ctr1 protein level in cells cultured in media with increased or decreased $\mathrm{Cu}$ conditions (Hardman et al., 2006). One important difference that must be taken into account when considering $\mathrm{Cu}$ or $\mathrm{Fe}$ status in the placenta in vivo in comparison with in vitro systems is that the placenta has a fetus attached, and hence fetal levels need to be considered for indicators of placental status. So, for example, it is not entirely surprising the $\mathrm{Cu}, \mathrm{Zn}$ superoxide dismutase 1 levels are not changed, because the steady-state levels of $\mathrm{Cu}$ 
in the placenta are not significantly changed, but the total amount transferred by the tissue are significantly reduced.

Virtually nothing is known about the transport mechanism for $\mathrm{Cu}$ once it is inside the placental cell. Presumably it involves the same $\mathrm{Cu}$ chaperones as described for other tissues (for a review, see Prohaska \& Gybina, 2004). Atox1 is a small $\mathrm{Cu}$ chaperone which has an essential role in delivering $\mathrm{Cu}$ to the $\mathrm{Cu}$-ATPase ATP7A (Hamza et al., 2001). The Menkes (ATP7A) and Wilson (ATP7B) proteins are $\mathrm{Cu}$-transporting ATPases that are defective in human $\mathrm{Cu}$ deficiency disorders. The two proteins have different cellular localisation and it is possible that they have different functions in the placenta (Muramatsu et al., 1998; Hardman et al., 2004). The data presented here showed no changes in expression of Atox1, ATP7A or ATP7B mRNA levels in the placenta. The absence of changes in mRNA levels was not unexpected, as the two $\mathrm{Cu}$-ATPases have been shown to be subjected to post-translational modification rather than transcriptional regulation by $\mathrm{Cu}$ (Paynter et al., 1994; Mercer \& Llanos, 2003).

Our data emphasise the importance of a sufficient intake of micronutrients, especially $\mathrm{Cu}$ and $\mathrm{Fe}$, during pregnancy for the normal development of the baby. Deficiency in one micronutrient can lead to imbalances in nutritional status in others, with potentially serious consequences both in the short and in the long term for the offspring. We have shown, for example, that maternal Fe deficiency results in hypertension in the offspring, and the present data would imply a similar outcome for $\mathrm{Cu}$ deficiency. It becomes more important, therefore, to develop an accurate and specific suite of markers for the assessment of $\mathrm{Cu}$ status in women of childbearing age and especially in pregnancy.

\section{Acknowledgements}

We are grateful to Donna Wallace, Wilma Strachan and Kathleen Simpson of the Biological Resources Unit for their expert assistance in animal husbandry. The present study was supported by the International Copper Association, the Scottish Executive Environment and Rural Affairs Department (SEERAD) and the European Union (EARNEST). The authors have no competing financial interests.

\section{References}

American Institute of Nutrition (1980) Second report of the ad hoc committee on standards for nutritional studies. J Nutr 110, 1726.

Andersen HS, Gambling L, Holtrop G \& McArdle HJ (2006) Maternal iron deficiency identifies critical windows for growth and cardiovascular development in the rat postimplantation embryo. J Nutr 136, G1171-G1177.

Bauerly KA, Kelleher SL \& Lonnerdal B (2005) Effects of copper supplementation on copper absorption, tissue distribution, and copper transporter expression in an infant rat model. Am J Physiol 288, G1007-G1014.

Chomczynski P \& Sacchi N (1987) Single-step method of RNA isolation by acid guanidinium thiocyanate-phenol-chloroform extraction. Anal Biochem 162, 156-159.

Danzeisen R, Fosset C, Page K, David S \& McArdle HJ (2002) Placental ceruloplasmin homologue is regulated by iron and copper and is implicated in iron metabolism. Am J Physiol 282, C472-C478.
Ebesh O, Barone A, Harper RG \& Wapnir RA (1999) Combined effect of high-fat diet and copper deficiency during gestation on fetal copper status in the rat. Biol Trace Elem Res 67, 139-150.

Gambling L, Charania Z, Hannah L, Antipatis C, Lea RG \& McArdle HJ (2002) Effect of iron deficiency on placental cytokine expression and fetal growth in the pregnant rat. Biol Rep 66, $516-523$.

Gambling L, Danzeisen R, Gair S, Lea RG, Charania Z, Solanky N, Joory KD, Srai SKS \& McArdle HJ (2001) Effect of iron deficiency on placental transfer of iron and expression of iron transport proteins in vivo and in vitro. Biochem J 356, 883-889.

Gambling L, Dunford S \& McArdle HJ (2004) Iron deficiency in the pregnant rat has differential effects on maternal and fetal copper levels. J Nutr Biochem 15, 366-372.

Hamza I, Faisst A, Prohaska J, Chen J, Gruss P \& Gitlin JD (2001) The metallochaperone Atox 1 plays a critical role in perinatal copper homeostasis. Proc Natl Acad Sci U S A 98, 6848-6852.

Hardman B, Manuelpillai U, Wallace EM, Monty JF, Kramer DR, Kuo YM, Mercer JF \& Ackland ML (2006) Expression, localisation and hormone regulation of the human copper transporter hCTR1 in placenta and choriocarcinoma Jeg-3 cells. Placenta 27, 968-977.

Hardman B, Manuelpillai U, Wallace EM, van de Waasenburg S, Cater M, Mercer JF \& Ackland ML (2004) Expression and localization of Menkes and Wilson copper transporting ATPases in human placenta. Placenta 25, 512-517.

Harris ZL, Klomp LW \& Gitlin JD (1998) Aceruloplasminemia: an inherited neurodegenerative disease with impairment of iron homeostasis. Am J Clin Nutr 67, 972S-977S.

Harris ZL, Takahashi Y, Miyajima H, Serizawa M, MacGillivray RTA \& Gitlin JD (1995) Aceruloplasminemia: a molecular characterization of this disorder of iron metabolism. Proc Natl Acad Sci USA 92, 2539-2543.

IOM (2001) Dietary reference intakes for vitamins and micronutrients. A report of the Panel for Micronutrients. Food and Nutrition Board, Institute of Medicine, Washington, DC: National Academy Press.

Keen CL, Hanna LA, Lanoue L, Uriu-Adams JY, Rucker RB \& Clegg MS (2003) Developmental consequences of trace mineral deficiencies in rodents: acute and long-term effects. J Nutr 133, 1477S-1480S.

Kuo YM, Gybina AA, Pyatskowit JW, Gitschier J \& Prohaska JR (2006) Copper transport protein (Ctr1) levels in mice are tissue specific and dependent on copper status. J Nutr 136, 21-26.

Lee J, Prohaska JR, Dagenais SL, Glover TW \& Thiele DJ (2000) Isolation of a murine copper transporter gene, tissue specific expression and functional complementation of a yeast copper transport mutant. Gene 254, 87-96.

McArdle HJ, Douglas AJ, Bowen BJ \& Morgan EH (1985) The mechanism of iron uptake by the rat placenta. J Cell Physiol 124, 446-450.

McArdle HJ, Douglas AJ \& Morgan EH (1985) Uptake of transferrin and iron by cultured rat placental cells. J Cell Physiol 122, 405-409.

Masters DG, Keen CL, Lonnerdal B \& Hurley LS (1983) Comparative aspects of dietary copper and zinc deficiencies in pregnant rats. J Nutr 113, 1448-1451.

Mazur A, Feillet-Coudray C, Romier B, Bayle D, Gueux E, Ruivard M, Coudray C \& Rayssiguier Y (2003) Dietary iron regulates hepatic hepcidin 1 and 2 mRNAs in mice. Metabolism 52, 1229-1231.

Mercer JF \& Llanos RM (2003) Molecular and cellular aspects of copper transport in developing mammals. J Nutr 133, 1481S-1484S.

Muramatsu Y, Yamada T, Moralejo DH, Suzuki Y \& Matsumoto K (1998) Fetal copper uptake and a homolog (Atp7b) of the Wilson's disease gene in rats. Res Commun Mol Pathol Pharmacol 101, 225-231.

Paynter JA, Grimes A, Lockhart P \& Mercer JF (1994) Expression of the Menkes gene homologue in mouse tissues lack of effect of copper on the mRNA levels. FEBS Lett 351, 186-190. 
Prohaska JR \& Brokate B (2002) The timing of perinatal copper defic iency in mice influences offspring survival. J Nutr 132, 3142-3145.

Prohaska JR \& Gybina AA (2004) Intracellular copper transport in mammals. J Nutr 134, 1003-1006.

Sunderman FW Jr, Zaharia O, Reid MC, Belliveau JF, O'Leary GP Jr \& Griffin H (1984) Effects of diethyldithiocarbamate and nickel chloride on glutathione and trace metal concentrations in rat liver. Toxicology 32, 11-21.

Vulpe CD, Kuo YM, Murphy TL, Cowley L, Askwith C, Libina N, Gitschier J \& Anderson GJ (1999) Hephaestin, a ceruloplasmin homologue implicated in intestinal iron transport, is defective in the sla mouse. Nat Genet 21, 195-199.
Waddell J, Steenbock H, Elvehjem C \& Hart E (1927) Iron in nutrition V. Iron salts and iron containing ash extracts in the correction of anemia. J Biol Chem 77, 777-795.

Wapnir RA, Gyasi I, Harper RG, Moyse J \& Teichberg S (1996) Placental copper transport in the rat. II: Effect of maternal copper deficiency. Placenta 17, 479-486.

Wildman RE, Hopkins R, Failla ML \& Medeiros DM (1995) Marginal copper-restricted diets produce altered cardiac ultrastructure in the rat. Proc Soc Exp Biol Med 210, 43-49.

Zhou B \& Gitschier J (1997) hCTR1: a human gene for copper uptake identified by complementation in yeast. Proc Natl Acad Sci USA 94, 7481-7486. 